日消外会誌 32 ( 4 )：1002 1006，1999年

症例報告

食道癌術後に挙上胃管が右気管支動脈と奇静脈弓により

\title{
絞扼壊死をきたした 1症例
}

\begin{tabular}{|c|c|c|c|c|c|c|c|}
\hline \multicolumn{8}{|c|}{ 大阪市立総合医療センター外科, 消化器外科 } \\
\hline 福長 & 洋介 & 東野 & 正幸 & 谷村 & 愼哉 & 藤本 & 泰久 \\
\hline 水上 & 健治 & 山崎 & 修 & 松山 & 光春 & 堀井 & 勝彦 \\
\hline 1野 & 匡宥 & 平田 & 早苗 & & & & \\
\hline
\end{tabular}

今回われわれは, 胸部食道癌に対する高位胸腔内胃管吻合術後に, 右気管支動脈と奇静脈弓により 胃管の絞扼壊死をきたした症例を経験したので報告した . 症例は59歳の男性 . | Iulm の1pl+0-|lb 型の 高分化型扁平上皮癌に対して, 低容量シスプラチンと $5 F U$ による術前化学療法を 2 週間行った後, 胸 部食道全摘・3領域リンパ節郭清・全胃管高位胸腔内吻合術を施行した 第 4 病日にショックとなりド レーンより消化液の流出を認めたため, 縫合不全による縦隔炎と診断した . 再開胸すると，右気管支 動脈と再縫合した奇静脈弓に挟まれた挙上胃管が兴の口側で壊死穿孔していたため, 壊死部胃管切除 ・頸部食道外瘻術を施行した . 術後は MOF に陥ったが集中治療にて回復し，协後に左結腸による 消化管再建術を施行し軽快退院した . 高位胸腔内での胃管再建は, 安全性が高く近年注目されている が , 右気管支動脈と奇静脈弓による絞扼壊死の報告は今回が初めてである . 右気管支動脈を兴の分枝 近くの大動脈弓付近まで剝離する，あるいは奇静脈弓の再縫合をしない，またはゆるくするなどの工 夫が必要と思われた .

Key words : necrosis of substituted stomach, esophageal cancer, intrathor acic esophagogastrostomy

はじめに

近年, 食道癌に対する手術手技, 術後管理も発達し, 長期的な予後の向上のみならず，急性期合併症の発生 率も低下してきている.しかしなお，外科手術の中で は手術手技が繁雑で合併症の発生が多いものの1つで ある．なかでも注意を要する合併症として，喀痰排出 障害と咳嗽反射低下に伴う術後肺炎や縫合不全があげ られるが, 頻度が少ないものの再建藏器の血流障害に 伴う壞死という問題も忘れてはならない，特に再建藏 器として最も頻用される胃管は, 主に壁内の血流に富 み右胃大網動静脈と右胃動静脈のみで胃弓隆部まで血 行が保たれるとされる11. しかし 縫合不全と関連した 胃先端部の血流の報告 ${ }^{2}$ や胃管壞死の報告 ${ }^{3)}$ も散見され る.また, 再建藏器を直視下に確認しながら吻合でき るという利点から，高位胸腔内吻合が安全とする報告 もみられる. 今回 われわれは胸部食道癌に対する高 位胸腔内吻合術後に, 右気管支動脈と奇静脈弓により

$<$ 1998年12月 9 日受理 > 別刷請求先 : 福長 洋介 ～534-0021 大阪市都島区都島本通2-13-22 大阪 市立総合医療センター消化器外科
胃管に絞扼壊死をきたした症例を経験したので，若干 の文献的考察を加えて報告する．

$$
\text { 症例 }
$$

患者：59歳，男性

主訴: 吐血

家族歴，既往歴 : 特記すべき事なし.

現病歴: 平成 7 年 3 月に食後吐血があり, 近医で行 われた内視鏡検査で食道病変を指摘された。

入院時現症 : 体格栄養中等度.貧血黄疸無く, 頸部 表在リンパ節も触知せず. 胸腹部の理学的所見にも異 常なし.

入院時検査成績: 一般検血，検尿，生化学的検査に 異常所見無く, 各種腫瘍マーカーも正常值であった .

食道造影 $X$ 線検査所見: 気管分岐部の口側より光

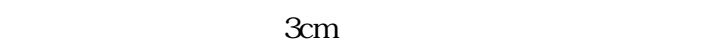
整像を認める (Fig.1).

上部消化管内視鏡検査所見 : 切歯列より $25 \mathrm{~cm}$ から $28 \mathrm{~cm}$ にかけて表面が平坦で発赤を伴う隆起性病変が みられ (Fig. 2a)，ルゴール染色で同部位を含め23cm から $30 \mathrm{~cm}$ まで広範囲にわたる不染を認め (Fig. 2b ) , 
Fig. 1 Barium esophagogram showing an light protruded lesion in the upper esophagus.

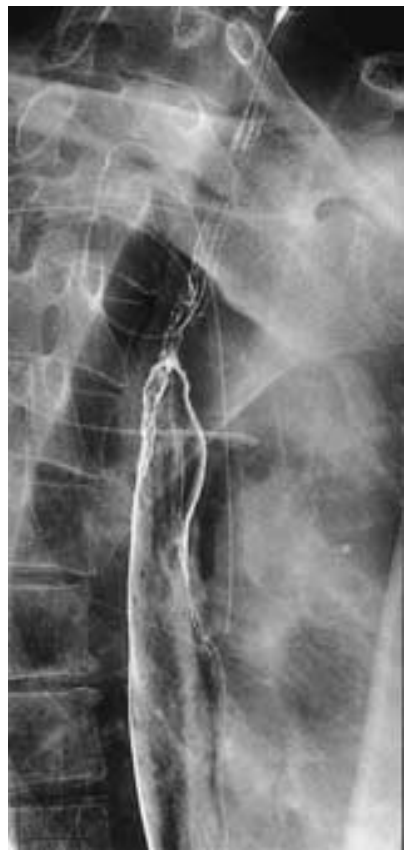

1pl+0-IIb と考えられた . 同部位からの生検で高分化 型扁平上皮癌と診断された。

以上より ,I ulm の最深部は MP の表層拡大型食道癌 の診断で,術前化学療法(5FU 500mg/body/day ,CIV , $\times 7$ 日間，CDDP 10mg/body/day，DIV，×5日間投薬 2 日間休薬) を 2 週間施行し, 平成 7 年 5 月17日胸部食 道全摘・3領域リンパ節郭清・全胃管高位胸腔内吻合 術を施行した . 術中および病理所見は，食道癌取扱い 規約 ${ }^{5)}$ に基づくと，Iulm，0-llb(Ch) ,ao (ep) ,no， Plo， $\mathrm{M}_{0}, \mathrm{R}_{3}, \mathrm{C}_{3}$ であった . しかし，第 4病日にショックと なりドレーンより消化液の流出を認めたため，経鼻胃 管 (NG チューブ) よりガストログラフィンで造影する と, 食道胃吻合部の肛門側より壁外への造影剂の漏出 を認めた (Fig. 3) . そこで, 部位不明ながらも縫合不 全による縦隔炎と診断し，同日再開胸を行った．右気 管支動脈と再縫合した奇静脈弓により，挟まれた挙上 胃管が午の口側で壊死穿孔していた (Fig.4). 壊死部 胃管切除・頸部食道外瘻・胸腔内洗浄ドレナージ術を 施行した．術後は一時的にMOFに陥ったが，人工呼吸 管理，持続血液透析などの集中治療にて回復し，4か月 後の 9 月29日左結腸による消化管再建術 (頸部血管吻 合による血流改善付加) を施行した．切除した胃管は
Fig. 2 a. Esophagoscopy showing a protruded lesion with a flat surface on the top from $25 \mathrm{~cm}$ to $28 \mathrm{~cm}$ from the mouth. b.T he esophageal mucosa including the protruded lesion from $23 \mathrm{~cm}$ to $30 \mathrm{~cm}$ from the mouth was not stained circumferential by iodine.
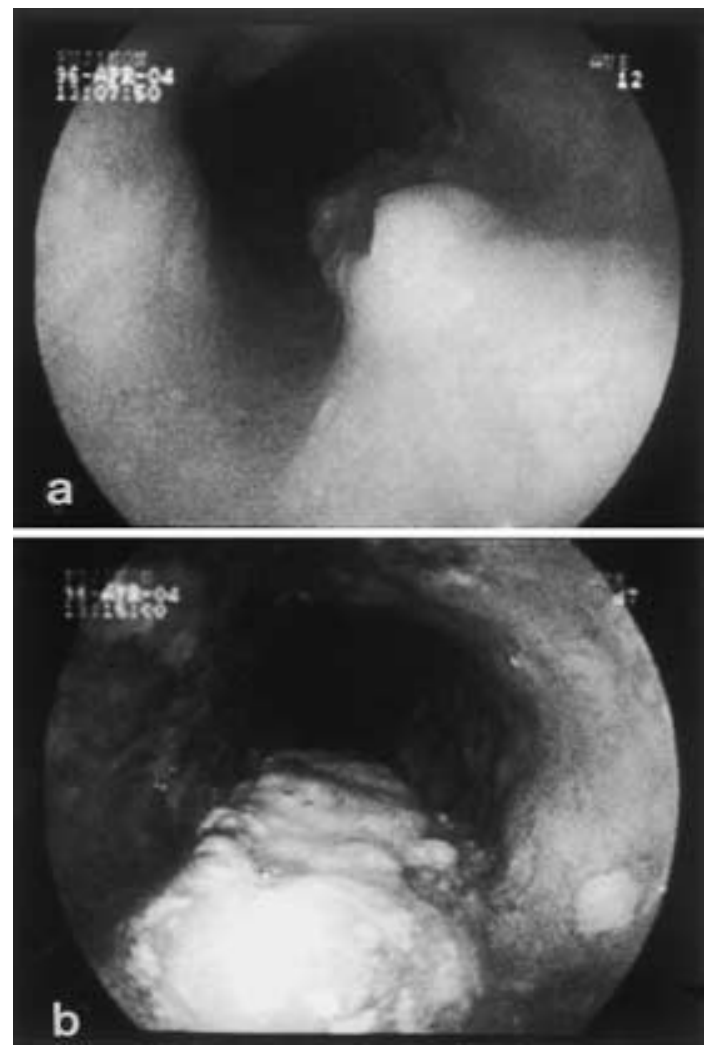

肉眼的および病理的に, 奇静脈弓が圧迫していた部位 より口側で黑く変色し，穿孔していた (Fig.5). 弚の 後は順調に経過し，初回手術より第258病日軽快退院し た。

\section{考察}

食道癌術後の再建藏器の血流は, 縫合不全の最も大 きな因子として以前より研究, 報告されてきた . 特に 胃管に関する血流の問題は，細胃管に形成するのか， あるいは全胃管で挙上するのかという問題も含めて， 非常に多くの報告と意見がある ${ }^{12(2) 67)}$.さらに，光の挙 上経路も再建胃管の血流あるいは緊張などにより縫合 不全の頻度に影響を与えるとされる．すなわち，後縦 隔経路では挙上距離が最も短いため縫合不全の率が低 いとの報告もみられる 建が, 挙上距離も後縦隔を通すため短く，直視下に胃 
Fig. 3 Postoperative contrast examination by nasogastric tube showing an extra digestion around the esophago-gastric anastomosis.

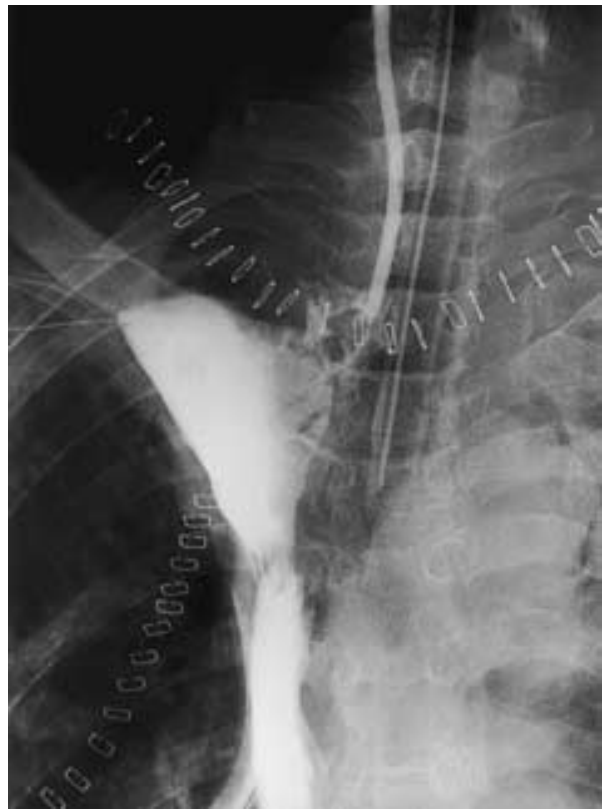

Fig. 4 Operative findings show ing a perforation with necrosis of the substituted stomach proximal to the azygos arch (Arrows ; showing the retied azygos arch ).

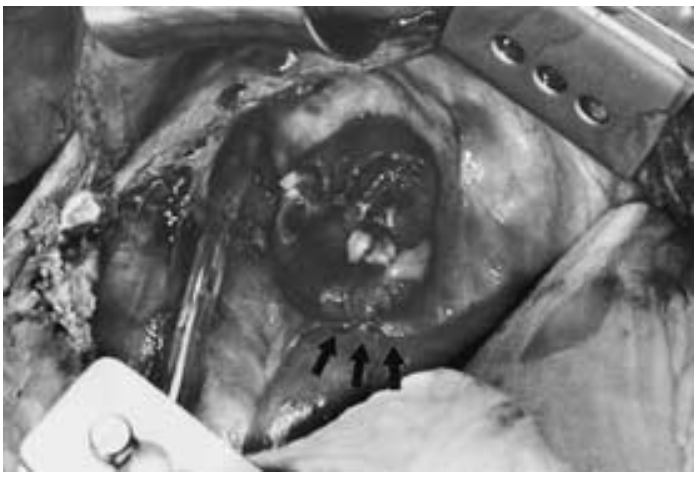

管を挙上できることから安全性が高いとの報告がみら れる ${ }^{4)}$. 一般に胸腔内吻合とは 左開胸開腹下における 下部食道癌に対する切除後の再建術と認識されてお り ${ }^{9)}$, 胸部中部食道癌に対しては胸部上部食道が残存 し，胸腔内食道の切除範囲が制限されるという考えか らあまり行われていなかった．しかし本症例では，左 右の上縦隔リンパ節郭清も行った上で胸部上部食道で
Fig. 5 a. Macroscopic findingn of the resected stomach from the mucosal side showing an apparent color contrast at the part of the compression. b. Histologic findings showing no mucosa with some congestions at the necrotic part (H-E stain, original magnification $\times 40$ ) .
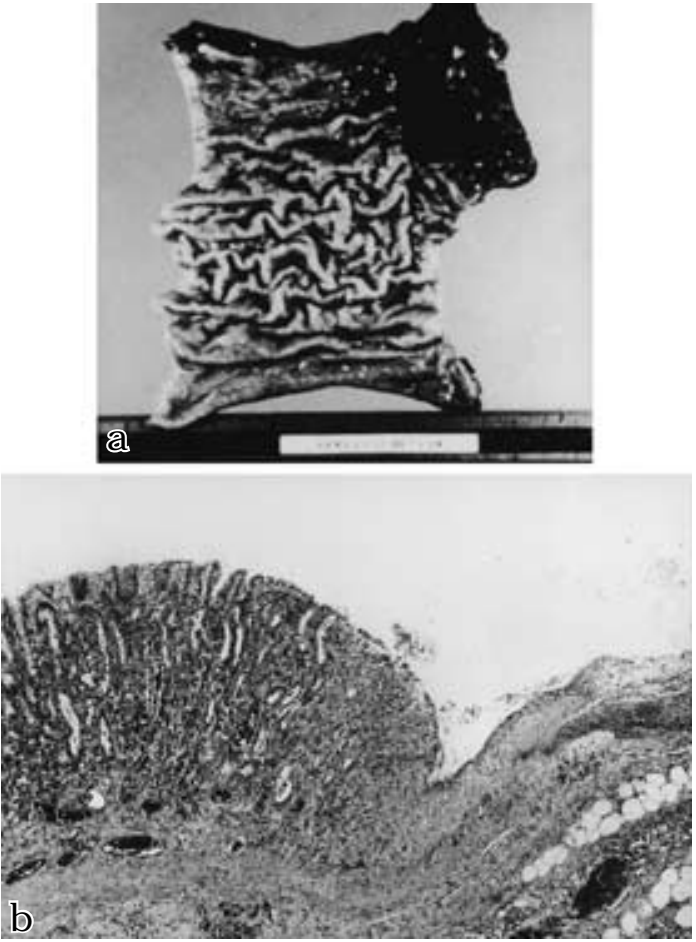

切除し，弚の上で胸腔内吻合を施行しえた．

われわれの施設でも，開院以来 3 年の間に，リンパ 節転移が光れほど広範でない表在型の胸部食道癌や腹 部食道癌を中心に，開腹先行の高位胸腔内胃管吻合術 を行っており，兴の安全性が確立されてきた．しかし 今回，前述したごとく右気管支動脈と奇静脈弓による 絞扼壊死という極めてまれな合併症が発生した .

右気管枝動脈の分枝はいくつかの変異があるもの の，一般には大動脈弓から分枝した後，1,2本の肋間動 脈を分枝し奇静脈弓の食道側を前方に横切り，右主気 管支へと分布する ${ }^{1011)}$. これは食道癌の手術後の気管 の血流に重要とされ ${ }^{1213)}$ ，これを確認し，腫瘍の影響 を受けていない場合は極力温存するようにしている． 従来後縦隔経路での食道胃管頸部吻合では，胃管挙上 に先立って右気管支動脈の左側で奇静脈弓を再縫合 し , さらに光の左方すなわち縦隔の中心側にテープを 通しておき挙上した。これにより，右気管支動脈の牽 
Fig. 6 Schema showing the pulled-up route of the substituted stomach between the right bronchial artery and the reconnected azy gos arch.

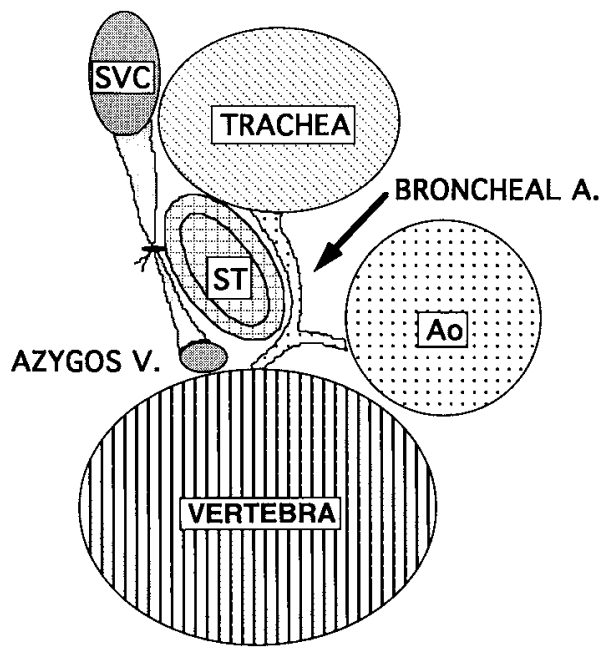

引切断を避け，また胃管の右胸腔内への拡張脱出を押 さえていた . 高位胸腔内吻合では直視下で器械による 食道胃管吻合を行うため，右気管支動脈の右側に胃管 をのせるように挙上する .さらに, 光の右側で胃管の 拡張脱出を押さえるために奇静脈弓を再縫合する (Fig. 6) . 本症例では, 右気管支動脈の緊張が強く，光 の間の胃管が絞扼したものと考えられた . 今回の教訓 として，1)右気管支動脈を，弚の分枝する肋間動脈を 処理することにより大動脈弓部近くまで剥離し，十分 にゆとりを持たせる．2)全胃管を挙上吻合した後に胃 管のたるみ程度をみて, 必要が無ければ奇静脈弓を再 縫合しない．あるいは緩く縫合する．3) NG チューブ の側孔を右気管支動脈の部位より口側に留置し，この 部位の胃管が膨張しないようにする.などの工夫が必 要と考えられた .

$$
\text { 文献 }
$$

1) 米沢 健, 土屋周二, 細井英雄ほか：食道再建用胃
管の挙上性と血流に関する臨床的, 実験的研究 .日 消外会誌 $13: 1-7,1980$

2) 金丸 仁,横山日出太郎,高山 豊ほか: 短胃動脈 に血管吻合を追加する胃管による食道再建術. 手 術 $47:$ 1447-1451, 1993

3) 大西祥平,高木 嚴, 国島和夫ほか：大胸筋皮弁に よる胸壁前挙上胃管壊死欠損部の修復 . 日消外会 誌 18 : 976一979,1985

4) 高木 嚴, 国島和夫, 陶山元一ほか : 胸部中下部食 道癌に対する胸部食道帏全摘 - 右胸腔内高位食道 胃吻合術。日胸外会誌 $40: 730-733,1992$

5) 食道疾患研究会編：食道癌取扱い規約. 第 8 版. 金 原出版, 東京, 1992

6) A kiyama $\mathrm{H}$, Miyazono $\mathrm{H}$, T surumaru $\mathrm{M}$ et al : U se of the stomach as an esophageal substitute. A nn Surg 188 : 606-610, 1978

7) 貴島 政, 松島孝雄, 阿南 晃ほか：食道再建用胃 管の太さと口側末梢の壊死. 外科 45: 1551一 1555, 1983

8) 鶴丸昌彦,宇田川晴司,梶山美明ほか：食道癌切除 術後再建経路 胸骨後. 外科 $58: 89-91,1996$

9) 田部康次, 大成亮次, 山本浩之ほか：胸部食道癌 Im に対する斜切開左開胸開腹食道抜去, 左胸腔内 食道再建術一患者のQOL を重視した縮小手術に ついて一.広島医 48:910—912, 1995

10) 舟波 裕, 奥山和明, 唐司則之ほか：食道癌手術視 野からみた気管支動脈の走行に対する解剖学的検 討。日外会誌 94:456一465, 1993

11) 舟波 裕, 奥山和明, 小出義雄ほか: 気管前面の微 細な気管支動脈の走行に対する解剖学的検究一食 道癌手術での温存を目的として一。目外会誌 96 : 208-212, 1995

12) 島 一郎：胸部食道癌根治手術における気管支動 脈ならびに迷走神経肺枝温存の意義 . 日胸外会誌 37 : 2305-2317, 1989

13) Nakahara R, Nimura $\mathrm{Y}$, Hayakawa $\mathrm{N}$ et al : Evaluation of tracheal mucosal blood flow during an extended radical operation for esophageal carcinoma : Clinical and experimental studies. Jpn J Surg 24 : 585-590, 1994 
A Case Report of Necr osis of the Substituted Stomach due to Compr ession by the Right Bronchial A rtery and the A zygos A rch after Radical Surgery for Esophageal Cancer

\author{
Y osuke F ukunaga, Masay uki Higashino, Shiny a T animura, Y asuhisa F ujimoto, \\ Kenji Mizugami, O samu Y amazaki, Mitsuharu Matsuyama, \\ Katsuhiko Horii, Masahiro Okuno and Sanae Hir ata \\ Department of Surgery, O saka City General Hospital, O saka, Japan
}

\begin{abstract}
A 59-y ear-old man was admitted in May 1996 due to esophageal cancer of the upper thoracic esophagus, of a protruding, superficial, expanding type that was unstained by iodine. A fter neoadjuvant chemother apy with a combination of cisplatin and 5-FU for 2 weeks, a radical operation with 3 -field lymphadenectomy was performed. A digestive reconstruction was made by intrathor acic esophago-gastrostomy. On the fourth postoper ative day, the patient demonstrated vital instability caused by severe mediastinitis due to an anastomotic leak. A thor acotomy was redone and the proximal one-third of the substituted stomach was confirmed to have necrosis and perfor ation because of comression of the right bronchial artery and the azy gos arch. Resection of the necrotic part of the stomach and plueral lavage were performed and a cervical esophagostomy was made. T he patient's condition improved despite transitional multiple organ failure about three months later. A digestive reconstruction $w$ as performed using the left colon while the patient was stable and he was discharged seven months later. A Ithough intrathor acic esophago-gastrostomy has been consider ed a safe option, this report seems to be the fir st case of such a severe complication. We must consider the anatomical positions of the substituted stomach and the right bronchial artery and azygos arch when we performe a digestive reconstruction following surgery for esophageal cancer.
\end{abstract}

Reprint requests : Y osuke F ukunaga Department of Surgery, O saka City General Hospital 2-13-22 Miy akojimahondori Miy akojima-ku O saka, 534-0021 JA PA N 